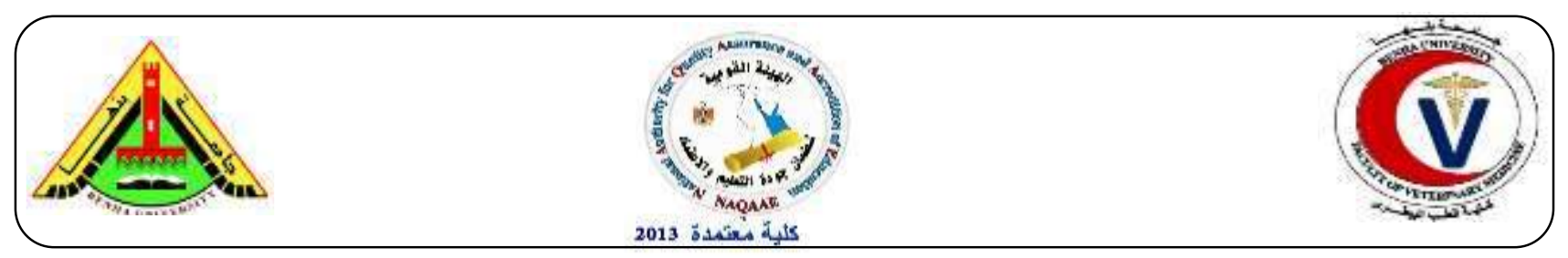

\title{
Heavy Metals Residues (Mercury and lead) Contaminating Nile and Marine Fishes
}

Loaloa Ali Shokr ${ }^{1}$, Mohamed Ahmed Hassan ${ }^{2}$, Engy Fawzy Elbahy ${ }^{1}$

${ }^{1}$ Department of Food Hygiene, Animal Health Research Institute, Dokki, Giza

${ }^{2}$ Department of Food Hygiene, Faculty of Veterinary Medicine, Benha University

\section{A B S T R A C T}

Mercury and lead are highly toxic heavy metals which are found in the environment and affect on public health hazard. Mercury and lead are chemical elements which cannot be destroyed or broken down through heat treatment or environmental degradation resulting in a variety of human health hazard as lethal, sub lethal, acute and chronic toxicity. Therefore, this study was performed on one hundred samples of freshwater fish Clarias grapinus (C. gariepinus) and Oreochromis niloticus (Oreochromis. niloticus) and marine water fish Sardina pilchardus (S. pilchardus) and Pagrus pagrus (P. pagrus) that were collected at different times from various fish markets in kafr El-sheikh governorate, Egypt for determination of their heavy metal residues by Atomic Absorption spectrophotometer (AAS). The results showed that the mean values of mercury were $1.10 \pm 0.02$, $0.89 \pm 0.01,0.72 \pm 0.01$ and $0.57 \pm 0.01(\mathrm{mg} / \mathrm{kg})$ in C.grapinus, O.niloticus, S.pilchardus and P.pagrus respectively. While, the mean values of lead were $0.64 \pm 0.01,0.49 \pm 0.01,0.33 \pm 0.01$ and $0.27 \pm 0.01$ $(\mathrm{mg} / \mathrm{kg})$ in such examined samples respectively. The public health significance and certain recommendations to control these serious pollutants were discussed.

Keywords: Heavy metal, lead, mercury, Clarias gariepinus, Oreochromis niloticus, Sardina pilchardus, Pagrus pagrus.

\section{INTRODUCTION}

Fish and its products have high quality proteins, fatty acids, very essential vitamins, minerals and lipids so they are very important source for nutrition (Metin et al., 2000 and Darwish, et al. 2003).

In addition, fish can absorb heavy metals through the gills and the gut then accumulate them in their tissues (Nammalawar, 1983).

The industrial discharges, Non treated sewages beside atmospheric changes and discharges from agriculture lead to contamination by heavy metals particularly in the areas near to these sources (Soresen, 1991).

Lead is known as a highly toxic element that can accumulate in bodies because its low level of removal. Colic, pain in the abdomen, anemia and encephalopathy are symptoms of lead toxicity. As well as, lead is considered as one of immunosuppressive agents in human (Chissolm, 1973). On the other hand, oral manifestation of lead poisoning includes ulcerative stomatitis, blue gingival lead line and grey spots on the buccal mucosa (Bryson, 
1989). Lead is an accumulative poison. It has hematological effect as it inhibits synthesis of hemoglobin and decrease erythrocytes life span. These may results in anemia (Alberti and Fidainz, 2002). It affects the nervous system causing irritability (Mert, 1987). The toxic effects of mercury are mainly on central nervous system and kidneys. Mercuric chloride causes severe kidney damage in both experimental animals and human. It seems that the proximal convoluted tubules are the prime target. In children, methyl mercury causes cerebral palsy and mental retardation (Timbrell, 1982). Acute ingestion of mercury causes burning of moth, throat, thirst, nausea, vomiting, abdominal pain and bloody diarrhea, in addition to oliguria, hematouria, albuminuria and casts (Clarck, 1989).

Therefore, the present study was applied to estimate mercury and lead residues in the flesh of fresh and marine water fishes as well as comparing of such residues with the safe permissible limits stipulated by the Egyptian Organization for Standardization (EOS, 2010).

\section{Materials and methods}

\subsection{Collection of samples:}

A random sample constituting; one hundred samples of fresh and marine fishes represented by $C$. grapinus, $O$. niloticus, $S$. pilchardus and P.pagrus (25 of each) were collected at various times fish stores in Kafr El-sheikh governorate, Egypt. The collected samples were kept individually in an insulated ice box and taken directly to the laboratory without undue delay. The weight of each fish sample was approximately $100 \mathrm{~g}$ except Clarias lazera where its weight was around $200 \mathrm{~g}$.

All collected samples were analyzed using Atomic Absorption Spectrophotometer for estimation of their heavy metals concentrations (mercury and lead) to determine their acceptability for human consumption. The basis of wet weight $(\mathrm{mg} / \mathrm{Kg})$ was used for determination of heavy metals of such examined samples.

\subsection{Washing procedures:}

Washing procedures were followed according to (Lars, 2003) to avoiding contamination, equipments and Glass wares and vessels were thoroughly cleaned with deionized water and soaked in hot diluted $\mathrm{HNO}_{3}(10 \%)$ for 24 hours and rinsed several times with deionized water and dried to ascertain that all the equipment were metal free. Further, the digestion vessels are put in a solution of soap and water for two hours then they washed many times by water from tap. As they were washed firstly by distilled water, then by a mixture of $(250 \mathrm{ml}$ water deionized, $200 \mathrm{ml}$ of concentrated hydrochloric acid and $80 \mathrm{ml}$ of Hydrogen peroxide with $10 \%$ nitric acid. All equipments were rinsed by deionized water then they are put in incubator to dry.

\subsection{Digestion technique:}

Based on the protocol of Staniskiene et al., (2006), one gram of every sample was minced with a very strong scalpel and digested by $10 \mathrm{ml}$ of digestion mixture $(60 \mathrm{ml}$ of $65 \%$ HNO3 and $40 \mathrm{ml}$ of $70 \%$ HCL) in screw capped tube after maceration for determination of lead residues. In regard to mercury, 0.5 gram of macerated sample was digested in $10 \mathrm{ml}$ of concentrated $\mathrm{H}_{2} \mathrm{SO}_{4} / \mathrm{HNO}_{3}$ solution (1:1). All tubes were closed tightly, the contents were shaken and left to stand at night at room temperature. Tubes were heated in worm water bath for 4 hours starting from $60^{\circ} \mathrm{C}$ till reach $110^{\circ} \mathrm{C}$ to ensure that all samples were completely digested. Then all tubes were strongly shaken for thirty minutes intervals. The tubes were to cool and diluted them by 1 $\mathrm{ml}$ deionized water $30 \%$ as well as reheated in a water bath at $70{ }^{\circ} \mathrm{C}$ as they completely digested. Each tube was diluted with deionized water till reach $25 \mathrm{ml}$ and the digest was filtered with Whattman filter paper No. 42.

\subsection{Analysis:}


All solutions which were standard, digested and blanks were absorbed by Atomic Absorption Spectrophotometer (VARIAN, Australia, model AA240 FS) and analyzed for mercury and lead concentrations. The apparatus has an auto sampler, digital absorbance and concentration readout capable of operating under the following conditions recommended by the instrument instruction. The level of each heavy metal in the blank also calculated and subtracted from each analyzed sample.

\subsection{Quantitative determination of heavy metal residues:}

Mercury absorbency was recorded directly from the digital scale of AAS and its concentration was calculated according to the following equation:

$$
\mathrm{C}_{1}=\left(\mathrm{A}_{1} / \mathrm{A}_{2}\right) \times \mathrm{C} \times(\mathrm{D} / \mathrm{W}) \mathrm{mg} / \mathrm{kg}
$$

Where,

$\mathrm{C}_{1}=$ concentration of mercury $(\mathrm{mg} / \mathrm{kg})$ wet weight.

$\mathrm{A}_{1}=$ Absorbency reading of sample solution.

$\mathrm{A}_{2}=$ Absorbency reading of standard solution.

$\mathrm{C}=$ Concentration of mercury on the standard solution.

$\mathrm{D}=$ Dilution factor of sample.

$\mathrm{W}=$ weight of each sample.

While, the concentration of lead was estimated according to the following equation:

$\mathrm{C}=\mathrm{R} \times(\mathrm{D} / \mathrm{W})$

Where,

$\mathrm{C}=$ concentration of lead $(\mathrm{mg} / \mathrm{kg})$ wet weight.

$\mathrm{R}=$ reading of digital scale of AAS.

$\mathrm{D}=$ Dilution of prepared sample.

$\mathrm{W}=$ Weight of the sample.

The concentration of each heavy metal in the blank solution was also calculated and subtracted from each analyzed sample.

\section{RESULTS}

It was showed from the results in table (1) that the frequency distribution of mercury were 18 samples in a percentage of $72 \%$ in C. lazera, 14 samples in a percentage of $56 \%$ in O.niloticus,
12 samples in a percentage of $48 \%$ in S.pilchardus and 9 samples in a percentage of $36 \%$ in P.pagrus.

The results achieved in table (2) indicated that the concentration of mercury in C.lazera was varied from 0.31 to 1.92 with an average of $1.10 \pm 0.02 \mathrm{mg} / \mathrm{kg}$. While the levels in O.niloticus varied from 0.26 to 1.65 with an average of $0.89 \pm 0.01 \mathrm{mg} / \mathrm{kg}$. However, such values in S.pilchardus ranged from 0.17 to 1.19 with an average of $0.72 \pm 0.01 \mathrm{mg} / \mathrm{kg}$. Such results were 0.11 to 1.08 with an average $0.57 \pm 0.01 \mathrm{mg} / \mathrm{kg}$ in P.pagrus.

Regarding to the summarized results given in (table 3), it is evident that the accepted samples of mercury were $(11,14,16$ and 20) with a percentages of 44, 56, 64 and $80 \%$ in C. lazera, O. niloticus, S. pilchardus, and P.pagrus, respectively. While, the unaccepted samples were $14,11,9$ and $5 \%$ with percentages of 56 , 44, 36 and $20 \%$ in such examined samples P.pagrus according to EOS (2010).

Results in table (4) indicated that the distribution of lead in C. lazera, O.niloticus, S. pilchardus, and P.pagrus were 15, 10, 9 and 7 samples with percentages of $60,40,36$ and 28 $\%$, respectively.

Results recorded in table (5) revealed that lead concentration ranged from 0.22 to 1.15 with mean value of $0.64 \pm 0.01 \mathrm{mg} / \mathrm{kgin}$ C.lazera, 0.14 to 0.87 , with mean valueof $0.49 \pm 0.01$ $\mathrm{mg} / \mathrm{kgin}$ O.niloticus, 0.10 to 0.62 with mean value of $0.33 \pm 0.01 \mathrm{mg} / \mathrm{kg}$ in S.pilchardus and 0.05 to 0.48 with mean valueof $0.27 \pm 0.01$ $\mathrm{mg} / \mathrm{kg}$ in P.pagrus. Finally, the results in table (6) revealed that the accepted samples of lead residues in C. grapinus, $\mathrm{O}$. niloticus, $\mathrm{S}$. pilchardus, and P.pagrus were $(13,17,18$ and 20) with percentages of $(52,68,72$ and $80 \%)$, however, the unaccepted samples were $(12,8$, 7 and 5) with percentages of (48, 32, 28 and $20 \%$ ), respectively. 
Table1: Incidence of Nile and marine fishes contamination with mercury $(n=25)$.

\begin{tabular}{lcc}
\hline \multicolumn{1}{c}{ Fish species } & No. & $\%$ \\
\hline C.grapinus & 18 & 72 \\
O. niloticus & 14 & 56 \\
S. pilchardus & 12 & 48 \\
P.pagrus & 9 & 36 \\
Total & 53 & \\
\hline
\end{tabular}

Table 2: Statistical analytical results of mercury residues $(\mathrm{mg} / \mathrm{Kg})$ in the examined samples of Nile and marine fishes $(n=25)$.

\begin{tabular}{|c|c|c|c|}
\hline Fish species & Min & Max & Mean \pm S.E \\
\hline C. grapinus & 0.31 & 1.92 & $1.10 \pm 0.02^{\mathrm{a}}$ \\
\hline O.niloticus & 0.26 & 1.65 & $0.89 \pm 0.01^{b}$ \\
\hline S.pilchardus & 0.17 & 1.19 & $0.72 \pm 0.01^{\mathrm{c}}$ \\
\hline P.pagrus & 0.11 & 1.08 & $0.57 \pm 0.01^{\mathrm{d}}$ \\
\hline
\end{tabular}

The difference between different letters in the same column were significant

High significant differences $(\mathrm{P}<0.01)$

Table 3: Validity of the examined Nile and marine fishes according to their mercury residues $(n=25)$.

\begin{tabular}{|c|c|c|c|c|c|}
\hline \multirow{2}{*}{ Fish products } & \multirow{2}{*}{$\begin{array}{c}\text { MRL } \\
(\mathrm{mg} / \mathrm{Kg})^{*}\end{array}$} & \multicolumn{2}{|c|}{ Accepted samples } & \multicolumn{2}{|c|}{ Unaccepted samples } \\
\hline & & No. & $\%$ & No. & $\%$ \\
\hline C. gariepinusazera & & 11 & 44 & 14 & 56 \\
\hline O. niloticus & & 14 & 56 & 11 & 44 \\
\hline & 0.5 & & & & \\
\hline S.pilchardus & & 16 & 64 & 9 & 36 \\
\hline Pagrus.pagrus & & 20 & 80 & 5 & 20 \\
\hline Total (100) & & 61 & 61 & 39 & 39 \\
\hline
\end{tabular}

* Maximum Residual Limit stipulated by Egyptian Organization for Standardization "EOS" (2010) 
Table 4: Incidence of Nile and marine fishes contamination with lead $(n=25)$.

\begin{tabular}{lcc}
\hline \multicolumn{1}{c}{ Fish species } & No. & $\%$ \\
\hline C. gariepinus & 15 & 60 \\
O. niloticus & 10 & 40 \\
S. pilchardus & 9 & 36 \\
P. pagrus & 7 & 28 \\
Total & 41 & 41 \\
\hline
\end{tabular}

Table 5: Statistical analytical results of lead residues $(\mathrm{mg} / \mathrm{Kg})$ in the examined samples of Nile and marine fishes $(\mathrm{n}=25)$.

\begin{tabular}{lccc}
\hline \multicolumn{1}{r}{ Fish species } & Min & Max & Mean \pm S.E \\
\hline C.gariepinus & 0.22 & 1.15 & $0.64 \pm 0.01^{\mathrm{a}}$ \\
O.niloticus & 0.14 & 0.87 & $0.49 \pm 0.01^{\mathrm{b}}$ \\
S.pilchardus & 0.10 & 0.62 & $0.33 \pm 0.01^{\mathrm{c}}$ \\
P.pagrus & 0.05 & 0.48 & $0.27 \pm 0.01^{\mathrm{d}}$ \\
\hline
\end{tabular}

The difference between different letters in the same column were significant at $(\mathrm{P}<0.01)$.

Table 6: Validity of the examined Nile and marine fishes according to their lead residues $(\mathrm{n}=25)$.

\begin{tabular}{lccccc}
\multicolumn{1}{c}{ Fish species } & $\begin{array}{c}\text { MRL } \\
(\mathrm{mg} / \mathrm{Kg})^{*}\end{array}$ & \multicolumn{2}{c}{ Accepted samples } & \multicolumn{2}{c}{ Unaccepted samples } \\
& & 13 & 52 & 12 & 48 \\
\hline C. gariepinus & 0.3 & 17 & 68 & 8 & 32 \\
O.niloticus & & 18 & 72 & 7 & 28 \\
S.pilchardus & & 20 & 80 & 5 & 20 \\
P.pagrus & & 68 & 68 & 32 & 32 \\
Total (100) & & & & & \\
\hline
\end{tabular}

* Maximum Residual Limit stipulated by Egyptian Organization for Standardization "EOS" (2010). 


\section{DISCUSSION}

The impacts of the heavy metals of primary concern ,mainly : Mercury and lead because of their known toxicity to human as well as including a variety of human health hazard as lethal, sub lethal, acute and chronic toxicity ( levensen and Barnard, 1988 ).

\section{Mercury:}

The high incidence of heavy metals under examination in C.lazera a harvested from Kafr El-Sheikh at locations may be attributed to different sewage industrial wastes as chemical fertilizers, super phosphate manufacturing; pesticides; salt; soda and other chemicals (Abd El-Hamid , 1994) .

Fish is the main source of methyl mercury for human. Mercury pollution arises mainly from both natural sources due to degassing of earth`s crust and by anthropogenic sources as the mercury had been used for numerous industrial applications. These sources are fossil, industries of chlorine, pulp, paper, and agricultural activities, all these sources lead to disposition of mercury in two forms which are dry and wet into aquatic environment (Sheffy, 1987).

These results of mercury concentrations were nearly similar to those obtained by Noha and Ghada (2007) who reported that the mean value of mercury in T. nilotica was $1.10 \pm 0.88$ $\mathrm{mg} / \mathrm{kg}$, Sohsah-Madiha (2009) who reported that such value was $0.98 \pm 0.08$ and $0.81 \pm 0.05$ $\mathrm{mg} / \mathrm{kg}$ in C. lazera and T. nilotica in large size fish.

Higher results were recorded by Guvin-Aralar (1990) who found that such value was 4.6 $\mathrm{mg} / \mathrm{kg}$ in $T$. nilotica. While, lower results were obtained by El- Nahas (2015) who reported that the mean value of mercury in T.nilotica and C.lazera were $0.46 \pm 0.03$ and $0.52 \pm 0.04 \mathrm{mg} / \mathrm{kg}$, respectively, and in agreement with Sohsah-Madiha (2009) recorded that such values were $0.49 \pm 0.05$ and $0.72 \pm 0.04 \mathrm{mg} / \mathrm{kg}$ in small size fish, respectively and El-Said (2016) who found that such mean value were $0.037 \pm 0.115$ and $0.074 \pm 0.017 \mathrm{mg} / \mathrm{kg}$ in T.nilotica and C.lazera, respectively. The same, Albedair (2012) who reported that the mean value of mercury in sardine was $0.055 \pm 0.011 \mathrm{mg} / \mathrm{kg}$.

Brain degeneration and peripheral neuropathy occur due to the exposure to organic mercury, GIT problems and coagulation of alimentary mucosa occur due to the exposure to inorganic mercury. In general, mercury is eliminated slowly from kidney and intestine so it is cumulative toxin (Radostits et al., 1996).

Accordingly, the consumption of fish and shell fish contaminated with mercury lead to minimata diseases in human being. The symptoms of disease were loss of vision, impaired cerebral function, paralysis and death (Matidaeta, 1972).

\section{Lead:}

The results of lead concentrations in the examined fish in the current study were nearly similar to Seddek et al. (1996) who mentioned that such value of lead in C.lazera was 0.456 and ranged from 0.30 to $0.90 \mathrm{mg} / \mathrm{kg}$ at the same respect,_Sayed (1995) recorded that the concentration of lead in Tilapia spp varied from 0.10 to $0.67 \mathrm{mg} / \mathrm{kg}$ and El-Said (2016) who reported that the mean value of lead in C.lazera was $0.4276 \pm 0.04 \mathrm{mg} / \mathrm{kg}$ while, in T.nilotica was $0.24 \pm 0.003 \mathrm{mg} / \mathrm{kg}$, and Hadeed et al. (2017) who reported that such mean value in $P$.pagrus for lead was $0.18 \pm 0.04$ $\mathrm{mg} / \mathrm{kg}$.

Lower results were recorded by El-Nahas (2015) was reported that lead concentration in T.nilotica was ranged from 0.01 to 0.25 with mean value of $0.08 \pm 0.02 \mathrm{mg} / \mathrm{kg}$ and 0.03 to 0.35 with mean value $0.14 \pm 0.02 \mathrm{mg} / \mathrm{kg}$ in 
C.lazera, Hamida et al. (2018) who recorded that such value of lead in S.pilchardus was $0.055 \pm 0.021 \mathrm{mg} / \mathrm{kg}$ and Gawish and Hoshi (2017) who reported that such value was 0.1868 (ppm) in Morgan fish.

Higher results was recorded by Mehouelet al. (2019) who reported that such value was $2.13 \pm 1.12 \mathrm{mg} / \mathrm{kg}$ in sardine, Gawish and Hosni (2017) who reported that such mean value was $0.4646 \mathrm{mg} / \mathrm{kg}$ in sardine. The high incidence of lead in the examined fish samples harvested from kafr El-sheikh at locations may be attributed to industrial discharge which found in the river Nile without any treatment, these discharges have high quantities of lead, mercury , cadmium, iron and copper .Also the using of fertilizers, untreated ,municipal pesticides may increase these metals. The industrial discharges contain heavy metals salts as lead, cadmium nichel, copper and mercury, these salts can harm fish at few thousands melligrams to one melligram/litter (Hisek, 1987 ).

Lead is one of the earliest heavy metals used by human in all forms and considered as one of the most toxic metals because of its cumulative effect as well as sever toxic effects (Ibels and Pollock ,1986). Lead can affect on congnitive growth, behavior disorders and disability of learning in children , furthermore it can cause hypertension and cardiac diseases in adults, (Commission of the European Communities "CEC", 2001).

Lead is avery toxic metal that can affect fetus because it remains in the pregnant women and women who feed their babies by breast which possess the same dangerous effects on the C.N.S(Dora, 2004). Lead accumulates in the aquatic environment due to the erosion of soil then accumulated in fish over permissible limit lead to chronic intoxication and effect on G.I.T, nervous systems, kidneys and blood (ASSRD, 2005).

\section{CONCLUSION}

The current study proved that there are great variations in the levels of mercury and lead in the examined samples of fish. In addition, the examined samples were significantly polluted with high levels of toxic metals which seriously affect the human health. In other words, the continuous consumption of these contaminated fish may result in public health hazard through progressive irreversible accumulation of such toxic pollutants in the human body. The potential harm from these metals suggest that people should not eat smaller quantities of fish known to accumulate heavy metals only ,but also they should eat a diversity of fish in order to avoid consuming unhealthy quantities of heavy metals.

\section{REFERENCES}

Abd El-Hamid, M.A. 1994. The scientific principles for fish production and management first Edn .El-Waffaliberary, Cairo, Egypt, pp.525.

ATSDR (Agency of Toxic Substances and Disease Registry). 2005. Toxicological profile for lead .U.S. Department of Health and Human Services, public Health Service, centers for Diseases control.

Atlanta, G.A. Alberti, Fidainz, A.A., 2002.Trace elements in food and meals consumed by students attending the faculty cafeteria. Science of Total Environment 15(1-2), 133-140.

Alturiq, Amani S., Albedair, Lamia A., 2012. Evaluation of some heavy metals in certain fish, meat and meat products in Saudi Arabian market. Egyptian Journal. Aquatic Research 38, 45-49.

Bryson, P.D., 1989.Comprehensive review in toxicology.Second Edn. Aspen Publishers Inc., Rock Vile, Maryland, Royal Cambridge Wells. pp. 456-484.

Chisolm, J., 1973. Management of increased lead absorption and lead poisoning. England Journal Medicine, 289: 10161017. 
Clark, R.B., 1989. Marine pollution, Oxford Science Publications, second Edn., Clarendan Press, Oxford, Chap., 5: 130134.

Commission of the European Communities"C.E.C", 2001. Official Journal of the European Commission Regulation (EC) No 46612001 of 8 march 2001 Setting maximum level for certain contaminants in food stuffs unties L77, 1-13. The council of 23 October 2001 on the limitation of certain emissions in to the air from large combustion plant. OJL 3027 .11-2001 PL.

Cuvin-Aralar, M.L.A., 1990. Mercury levels in the sediment water and selected fin fishes of Laguna Lake. The Philippines. Aquacultures 84-277.

Darwish, A. M., El-Mossalami, M.K., ElBassuony, R.A. et al. 2003. Quality assurance of some fatty fishes. Assuit Veterinary Medicine Journal. 49(98): 79-96.

Diaz, C., Gonzalez, A., Frias, I., Hardisson, A. Lozano, G. et al., 1994. Concentration of mercury in fresh and salt marine fish from the Canary Islands. J. Food Protection. 57(3): 246-248.

Dorea, J.G., 2004. Mercury and lead breastfeeding. British Journal Nutrition. 92 (1): 21 .

Egyptian Organization for Standardization and Quality Control "EOS", 2010. Levels for certain contaminants in foodstuffs. No 7136/2010. Egyptian Standards, Ministry of Industry, Egypt.

El-Nahas, S.B., 2015. Heavy metal residues in fresh water fish. Thesis, Master

Veterinary Medicine (Meat Hygiene). Faculty Veterinary Medicine, Benha University, Egypt.

El-said, Marwa A.S.M., 2016. Heavy metal residues in imported and local fishes in Egypt. Thesis, Master of Veterinary Medicine, Beni Suef University, Egypt.

Finerty, M., Maden, J., Feagly, S. Grodner, R.et al. 1990. Effect of environment and seasonality on metal residues in tissues of wild and pond raised crayfish in Southern Louisiana. Archives of Environmental Contamination and
Toxicology Journal, 19: 94-998.

Food Stuffs Cosmetics and Disinfectant Act, 2007. Regulations relating to metals in foodstuffs (No.1518). Food Government Gazette, Johannesburg, South Africa.

Global Agricultural Information Network "GAIN", 2014. China's Maximum Levels for Contaminants in Foods. GAIN Report No.1

Hadeed Halima A., Aljetawi, A .A. Alhemmali., E. M., et al. 2017. Determination of some essential and toxic heavy metals in liver tissue of four marine fish species from cost of Misurata, Libya. First National Conference on Marine and Ground water pollution (first NCMGP 2017).

Ibels, L., Pollock, 1986. Lead intoxication. Mod. Toxicology, 1:387-410.

Lars, J., 2003. Hazards of heavy metal contamination. British Medicine Bullet journal. 68: 167-182.

Levensen, H. Barnard, W.D., 1988 .Waste in Warine Environmental Hemisphere Publishing Corporation. Cambridge, New York, London.Chap.6, 123-136.

Maha M., Hosni, Inas M., 2017. Assessment of some heavy metals in the economic fishes in Hail market, Kingdom of Saudi Arabia. Current Research in Biosciences and Plant Biology, 4(2):715.

Mammalwar, P., 1983. Heavy metal pollution in the marine environment. Science Reporter, 3: 158.

Matida, Y., Kumud, H. , Kimura , S. , Saiga ,Y. , Nose, T. , Yokote, M., Kawatsu, H.et al. 1972. Toxicity of mercury compounds to aquatic organisms and accumulation of the compounds by the organism, Bull. Fresh water fish. Research Lab, 21 -197.

Mehoul, Feta, Bouayad Leila., Hammoudi, A., Ayadi Ourda., RegadFifi et al. 2019. Evaluation of the heavy metals (Mercury, lead and cadmium) contamination of sardine (Sardina pilchardus) and sword fish (Xiphias gladius) fished in three Algerian coasts. Journal of Veterinary World, 2: 7-11

Metin, S.I., Erkan, N. ,V erlik, C., Ozden, C. , Baygar, T.; Kalafatoglu, H.Gun, H. et al., 2000.Influence of modified atmosphere 
packaging on shelf life of fish-salami, Fleish Witchcraft Inc., 4: 49-51.

Mirlean N., Larned, Nikora S.T., V., Kulters V.T. et al. 2005. Mercury in lakes and lake fishes on a condensation-industry gradient in Brazil. Chemosphere, 60(2); 226-236.

Needleman, H., 1980. Low level lead exposure .The clinical implication of current research, Raven press NewYork.

Noha R.M.A, Ghada, S.E.S .2007. Heavy metals residue in some fresh Egyptian fishes. Veterinary Medicine Journal, 55(3):787-798.

Radostits, O.M., Blood, D.C., Gay, C.C. et al. 1996. Veterinary Medicine. Atext book of the disease of cattle, sheep, pig, goats and horses. Tenth Edn.ElBs with Bailliere Tindall, London.

Sayed, M.M. 1995.Toxicological studies on some metallic, pollutants in Rivers at Assuit Governorate. Faculty Veterinary Medicine. Assuit University, Egypt.

Seddek, A.S.H ; Salem ,D.A .; El-Sawi , N.M, Zaky, Z.M .et al 1996.Cadmium, lead, Nickel, Copper, Manganese and fluorine level sin River Nile Fish. Assuit Veterinary Medicine Journal, 34:95.
Shibamoto, T. Bjeldanes, L.F. 1993. Introduction to food toxicology. San Diego, California. Food Science and Technology Journal, Academic Press XIII, 213S. ISBN0-12-640025-3

Sohsah-Madiha A.M. 2009. Studies on some heavy metal residues in fresh water fish with special reference to water environmental pollution. Ph. D Thesis (Meat Hygiene), Faculty Veterinary Medicine, Benha University, Egypt.

Sorensen, E.M.B. 1991. Metal poisoning in fish. CRC Press, Florida

Staniskiene, B.; Matusevicius, P.; Budreckiene, P., Skibniewska, K.A. et al. 2006. Distribution of heavy metals in tissues of freshwater fish in Lithuania. Polish Journal of Environmental Studies, 15(4): 585-591.

Tibrell, J.A. 1982. Principles of biochemical toxicology. Taylor and Francies Ltd., London. 